\title{
Effect of oxygen on breathing irregularities during haemodialysis in patients with chronic uraemia
}

\author{
J.C.H. Yap, Y.T. Wang, S.C. Poh
}

Effect of oxygen on breathing irregularities during haemodialysis in patients with chronic uraemia. J.C.H. Yap, Y.T. Wang, S.C. Poh. CERS Journals Ltd 1998.

ABSTRACT: Hypoxaemia and breathing irregularities have been shown to occur during haemodialysis in patients with chronic renal failure. This study examined the role of hypoxia in the genesis of the irregular breathing during haemodialysis.

The ventilatory patterns using respiratory inductance plethysmography and arterial blood gases were studied in seven males with chronic renal failure on long-term haemodialysis. The study was carried out before and during dialysis on one day without (D1) and another day with intranasal oxygen at $4 \mathrm{~L} \cdot \mathrm{min}^{-1}(\mathrm{D} 2)$.

On D1, mean (sd) arterial oxygen tension $\left(P_{\mathrm{a}}, \mathrm{O}_{2}\right)$ fell $1.9(0.9) \mathrm{kPa}(\mathrm{p}<0.001)$ and mean minute ventilation $\left(V^{\prime} \mathrm{E}\right)$ fell $1.9(1.1) \mathrm{L} \cdot \mathrm{min}^{-1}(\mathrm{p}<0.01)$ during dialysis. The arterial carbon dioxide tension $\left(\mathrm{Pa}_{\mathrm{a}} \mathrm{CO}_{2}\right)$ did not show a significant decrease $(4.7(0.2) \mathrm{kPa}$ before and 4.6 (0.2) $\mathrm{kPa}$ during dialysis). Cumulative number of apnoeas was 64 and the coefficients of variation $(\mathrm{COV})$ of respiratory frequency $\left(f_{\mathrm{R}}\right)$ and tidal volume $(V T)$ were 29.6 (11.9) and $38.2(11.9) \%$, respectively. On D2, mean $P \mathrm{a}, \mathrm{O}_{2}$ remained stable (20.4 (4.1) $\mathrm{kPa}$ before, 21.3 (4.1) $\mathrm{kPa}$ during dialysis). There was no significant change in mean $V^{\prime} \mathrm{E}\left(6.4(0.9) \mathrm{L} \cdot \mathrm{min}^{-1}\right.$ before, $5.5(0.5) \mathrm{L} \cdot \mathrm{min}^{-1}$ during dialysis $) . \mathrm{Pa}_{\mathrm{a}} \mathrm{CO}_{2}$ decrease was not significant but the fall was greater $(4.8(0.1) \mathrm{kPa}$ before, $4.5(0.5) \mathrm{kPa}$ during dialysis). Cumulative number of apnoeas was 94 and the COVs of $f \mathrm{R}$ and $V \mathrm{~T}$ were $35.8(5.1)$ and $40.5(11.3) \%$, respectively.

Oxygen administration did not significantly affect the haemodialysis-induced changes in ventilation and breathing pattern, despite a significant protective effect from the fall in arterial oxygen tension. It was concluded that the fall in arterial oxygen tension is not the main determinant of breathing irregularities during haemodialysis.

Eur Respir J 1998; 12: 420-425.
Dept of Respiratory Medicine, Tan Tock Seng Hospital, Singapore

Correspondence: J.C.H. Yap

Dept of Respiratory Medicine

Tan Tock Seng Hospital

Moulmein Road

Singapore 308433

Fax: 0652532884

Keywords: Breathing pattern haemodialysis

oxygen administration

Received: August 121996

Accepted after revision March 101998
A decrease in arterial oxygen tension has been noted in patients undergoing chronic haemodialysis. This dialysisrelated hypoxaemia has been attributed mainly to alveolar hypoventilation and a ventilation-perfusion imbalance [112]. During dialysis the arterial oxygen tension $\left(\mathrm{Pa}, \mathrm{O}_{2}\right)$ decreases by $1.3-2 \mathrm{kPa}$ and returns to baseline after the procedure [4]. This fall in $\mathrm{Pa}, \mathrm{O}_{2}$ may not be tolerated by patients with chronic renal failure who may also have cardiopulmonary disease [13]. Supplemental oxygen therapy may be required to correct the hypoxaemia [1,14-15].

In a study by DE BACKER et al. [16], an irregular breathing pattern during haemodialysis was found. It is known that hypoxaemia is associated with periodic and irregular breathing in awake normal adults [17-20]. It was proposed that the extrapulmonary excretion of carbon dioxide into the dialysate resulted in carbon dioxide becoming less of a stimulus for respiration, causing in a shift of control to the hypoxic-sensitive peripheral chemoreceptors and a consequent unstable breathing pattern. In a subsequent study, Heyrman et al. [21] showed that the administration of oxygen abolished irregular breathing without any change in total ventilation. They explained that the restoration of stable breathing was due to the "switching off" of the peripheral chemoreceptor drive.
In this study, the role of $\mathrm{Pa}_{\mathrm{a}} \mathrm{O}_{2}$ in the stability of breathing during haemodialysis was re-examined. It was felt that if low $\mathrm{Pa}, \mathrm{O}_{2}$ was the major drive to ventilation, switching off the peripheral chemoreceptors by hyperoxia should also result in a further fall in total ventilation, besides removing the irregularity. Respiratory inductance plethysmography (RIP) was used to measure both qualitative and quantitative data and to overcome the problem of using a mouthpiece, which has been reported to influence the breathing pattern [22].

\section{Patients and methods}

\section{Study subjects}

Seven male patients, with chronic renal failure due to various causes, undergoing three times weekly $4 \mathrm{~h}$ haemodialysis for at least 6 months, were studied. All patients gave informed consent. Their mean (SD) age was 37.4 (8.1) yrs, with a range of 29-49 yrs. They had normal static and dynamic lung volumes and they remained clinically stable throughout the study. All had normal chest radiographs. There was no history suggestive of sleep apnoea syndrome in any of the patients. 


\section{Study design}

Dialysis was performed with an open, two-needle, singlepass system with a Single Unit Gambro AIC-10 machine. A cuprophane type membrane and an acetate containing dialysate were used. The surface area of the membrane was $1.2 \mathrm{~m}^{2}$. The dialysate flow was kept constant at 500 $\mathrm{mL} \cdot \mathrm{min}^{-1}$ and the blood flow at $200 \mathrm{~mL} \cdot \mathrm{min}^{-1}$.

Blood specimens were collected in heparinized syringes from the arterial line before dialysis at time 0 , and then 60 and $120 \mathrm{~min}$ after the onset of dialysis. Blood $\mathrm{pH}$, arterial carbon dioxide tension $\left(\mathrm{Pa}, \mathrm{CO}_{2}\right), \mathrm{Pa}_{\mathrm{a}} \mathrm{O}_{2}$ and bicarbonate $\left(\mathrm{HCO}_{3}\right)$ were measured with a Radiometer Copenhagen ABL 30 Acid Base Analyser.

The patients were studied in a semirecumbent position. RIP was carried out using a computerized system, Respigraph $^{\mathrm{TM}}$. Approximately $15 \mathrm{~min}$ before the start of haemodialysis, the RIP was calibrated and validated during tidal breathing in a semirecumbent position using a previously validated method [23]. Calibration of RIP was performed for $10 \mathrm{~min}$ or a total of 250 breaths to obtain rib cage and abdominal gains. In a second procedure, the volume signal derived from RIP measurement was compared with the signal from the spirometer for 10 breaths to obtain new semiquantitative gains. Finally, the volume was validated with 10 breaths to obtain the mean percentage deviation of the Respigraph ${ }^{\mathrm{TM}}$ tidal volume from the Spirometer tidal volume. The quantitative calibration was only accepted if the validation per cent error was $\pm 10 \%$, and $90 \%$ of the breath-to-breath per cent error was $\pm 15 \%$. Once this was done, the semiquantitative RIP measurements were obtai-ned after each $15 \mathrm{~min}$ epoch. Analogue tracings of the rib cage (RC), abdomen (AB) and sum components of the RIP were displayed on a screen. This could be converted to an envelope display which also showed the oxygen saturation $\left(\mathrm{S}_{\mathrm{a}}, \mathrm{O}_{2}\right)$, recorded by an Ohmeda Biox 3 Pulse Oximeter (Ohmeda, CO, USA), and a wrist actigraph signal. The number, type and duration of apnoeas were also displayed. After every $15 \mathrm{~min}$ epoch, a compressed plot of the breathing pattern was printed out. The semiquantitative measurements that were taken were: tidal volume $(V \mathrm{~T})$, minute ventilation $\left(V^{\prime} \mathrm{E}\right)$ and mean inspiratory flow $(V \mathrm{~T} / t \mathrm{I})$. The other parameters were inspiratory time $(t \mathrm{I})$, expiratory time $(t \mathrm{E})$ and respiratory frequency $(f R)$. The epochs at 0,60 and $120 \mathrm{~min}$ were analysed. They were the average measurements of the last 15 min before each set interval time. The breathing pattern was also recorded on a eight-channel Gould Recorder $2800 \mathrm{~S}$. The breathing patterns on these recordings were analysed manually. At the end of the study, validation of semiquantitative measurements was repeated. The data were accepted only if the per cent error was $\pm 10 \%$, with $90 \%$ of the breath-to-breath validation $\pm 15 \%$ different from the spirometric $V \mathrm{~T}$.

The study was carried out on 3 days and at the same time each day. The time from the last dialysis to each study day was the same. The purpose of the study on the first day was to get the patients accustomed to the equipment, and the data were not analysed. On the second day (D1), the above measurements and breathing patterns were studied and analysed during $2 \mathrm{~h}$ of haemodialysis. This was repeated on the third day (D2) with intranasal supplemental oxygen at $4 \mathrm{~L} \cdot \mathrm{min}^{-1}$.

\section{Analysis of data}

Statistical analyses of differences in measurements from the predialysis value, as well as between the days, were performed by analysis of variance (ANOVA). A multiple comparison test, Scheffe's test, was used if the ANOVA was significant. The numbers of apnoeas on each study day were compared using a paired t-test.

\section{Results}

This study showed a highly significant fall in mean $P \mathrm{a}, \mathrm{O}_{2}$ during haemodialysis ( $\mathrm{p}<0.001$; table 1$)$. The mean (SD) decrease in $\mathrm{Pa}_{\mathrm{a}} \mathrm{O}_{2}$ was $1.9(0.9) \mathrm{kPa}$ by the second hour. This fall was $13.7(6.2) \%$ of the predialysis value (table 2). The individual $\mathrm{Pa}, \mathrm{O}_{2}$ did not fall below $10.7 \mathrm{kPa}$ during the $2 \mathrm{~h}$ of study. When intranasal oxygen at $4 \mathrm{~L} \cdot \mathrm{min}^{-1}$ was administered, their mean $\mathrm{Pa}, \mathrm{O}_{2}$ was maintai-ned at a high level throughout haemodialysis $(20.4$ (4.1) $\mathrm{kPa}$ predialysis and 21.3 (4.1) $\mathrm{kPa}$ at the second hour) (table 2). $\mathrm{Pa}_{\mathrm{a}} \mathrm{CO}_{2}$ did not show any significant decrease during the $2 \mathrm{~h}$ of the study on both days. However, the fall in $\mathrm{Pa}_{\mathrm{a}} \mathrm{CO}_{2}$ on D2 was greater (tables 2 and 3). The $\mathrm{pH}$ increased significantly by the second hour on both days $(\mathrm{p}<0.01$ on $\mathrm{D} 1$ and $\mathrm{p}<0.05$ on D2). The serum bicarbonate also showed a small rise with haemodialysis.

The mean $V^{\prime} \mathrm{E}, V \mathrm{~T}$ and $V \mathrm{~T} / t \mathrm{I}$ were the average of measurements taken from five out of seven patients, as the calibration of semiquantitative data of the other two did not meet the criteria for acceptance. After 120 min of haemodialysis in D1, $V^{\prime}$ 'E fell significantly from 7.4 (1.6) to 5.5 (0.9) $\mathrm{L} \cdot \mathrm{min}^{-1}(\mathrm{p}<0.01$; table 1$)$. On the day with oxygen administration, $V^{\prime}$ E decreased from $6.4(0.9)$ to $5.5(0.5)$

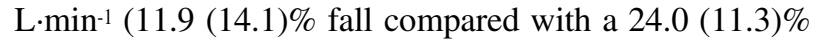
fall on D1) (tables 2 and 3). This fall in $V^{\prime} E$ was not significant. The mean $V$ T was also decreased on both days but

Table 1. - Blood gases and ventilation parameters during haemodialysis on the second day (D1)

\begin{tabular}{|c|c|c|c|}
\hline & $0 \mathrm{~min}$ & $60 \mathrm{~min}$ & $120 \mathrm{~min}$ \\
\hline$P \mathrm{a}, \mathrm{O}_{2} \mathrm{kPa}$ & $\begin{array}{l}13.9 \\
(0.7)\end{array}$ & $\begin{array}{l}11.8 \\
(0.9)^{* * * *}\end{array}$ & $\begin{array}{l}12.0 \\
(0.6) * * *\end{array}$ \\
\hline$P \mathrm{a}, \mathrm{CO}_{2} \mathrm{kPa}$ & $\begin{array}{l}4.7 \\
(0.2)\end{array}$ & $\begin{array}{c}4.8 \\
(0.2)\end{array}$ & $\begin{array}{l}4.6 \\
(0.2)\end{array}$ \\
\hline $\mathrm{pH}$ & $\begin{array}{l}7.393 \\
(0.023)\end{array}$ & $\begin{array}{l}7.399 \\
(0.021)^{* *}\end{array}$ & $\begin{array}{l}7.418 \\
(0.025)^{* *}\end{array}$ \\
\hline $\mathrm{HCO}_{3} \mathrm{mmol} \cdot \mathrm{L}^{-1}$ & $\begin{array}{l}21.4 \\
(2.0)\end{array}$ & $\begin{array}{l}22.0 \\
(1.2)\end{array}$ & $\begin{array}{l}22.8 \\
(1.4)\end{array}$ \\
\hline$V^{\prime} \mathrm{E} \quad \mathrm{L} \cdot \mathrm{min}^{-1}$ & $\begin{array}{l}7.4 \\
(1.6)\end{array}$ & $\begin{array}{l}6.2 \\
(1.0)^{* *}\end{array}$ & $\begin{array}{l}5.5 \\
(0.9)^{* *}\end{array}$ \\
\hline$V \mathrm{~T} \mathrm{~mL}$ & $\begin{array}{l}410 \\
(46.8)\end{array}$ & $\begin{array}{l}388.8 \\
(22.1)\end{array}$ & $\begin{array}{l}376.2 \\
(31.0)\end{array}$ \\
\hline$f \mathrm{R}$ breaths $\cdot \mathrm{min}^{-1}$ & $\begin{array}{l}18.5 \\
(3.9)\end{array}$ & $\begin{array}{l}15.9 \\
(3.0)^{* * *}\end{array}$ & $\begin{array}{l}14.6 \\
(2.4)^{* * *}\end{array}$ \\
\hline$V \mathrm{~T} / t \mathrm{I} \quad \mathrm{L} \cdot \mathrm{s}^{-1}$ & $\begin{array}{l}358.4 \\
(59.5)\end{array}$ & $\begin{array}{l}327.8 \\
(50.0)\end{array}$ & $\begin{array}{l}297.0 \\
(36.3)\end{array}$ \\
\hline$t \mathrm{I} \mathrm{s}$ & $\begin{array}{c}1.21 \\
(0.25)\end{array}$ & $\begin{array}{c}1.39 \\
(0.37)\end{array}$ & $\begin{array}{l}1.44 \\
(0.28)^{*}\end{array}$ \\
\hline$t \mathrm{E} \mathrm{s}$ & $\begin{array}{c}1.98 \\
(0.46)\end{array}$ & $\begin{array}{l}2.39 \\
(0.51)^{* * *}\end{array}$ & $\begin{array}{l}2.57 \\
(0.53) * * *\end{array}$ \\
\hline
\end{tabular}

$\overline{\text { All values are expressed as mean (sD). } P \mathrm{a}, \mathrm{O}_{2} \text { : arterial oxygen }}$ tension; $P \mathrm{a}_{1} \mathrm{CO}_{2}$ : arterial carbon dioxide tension; $V$ 'E: minute ventilation; $V$ T: tidal volume; $f \mathrm{R}$ : respiratory frequency; $V \mathrm{~T} / t \mathrm{t}$ : mean inspiratory flow; $t \mathrm{I}$ : inspiratory time; $t \mathrm{E}$ : expiratory time. $*: \mathrm{p}<0.05 ; * *: \mathrm{p}<0.01 ; * * * \mathrm{p}<0.001$ versus time $0 \mathrm{~min}$. 
Table 2. - Blood gases and ventilation parameters during haemodialysis with intranasal oxygen on the third day (D2)

\begin{tabular}{|c|c|c|c|}
\hline & $0 \min$ & $60 \min$ & $120 \mathrm{~min}$ \\
\hline$\overline{P a}, \mathrm{O}_{2} \mathrm{kPa}$ & $\begin{array}{l}20.4 \\
(4.1)\end{array}$ & $\begin{array}{l}22.9 \\
(7.0)\end{array}$ & $\begin{array}{l}21.3 \\
(4.1)\end{array}$ \\
\hline$P \mathrm{a}, \mathrm{CO}_{2} \mathrm{kPa}$ & $\begin{array}{l}4.8 \\
(0.1)\end{array}$ & $\begin{array}{c}4.7 \\
(0.4)\end{array}$ & $\begin{array}{c}4.5 \\
(0.5)\end{array}$ \\
\hline $\mathrm{pH}$ & $\begin{array}{l}7.399 \\
(0.026)\end{array}$ & $\begin{array}{l}7.403 \\
(0.02)\end{array}$ & $\begin{array}{c}7.433 \\
(0.034) *\end{array}$ \\
\hline $\mathrm{HCO}_{3} \mathrm{mmol} \cdot \mathrm{L}^{-1}$ & $\begin{array}{l}22.2 \\
(1.3)\end{array}$ & $\begin{array}{l}21.9 \\
(1.1)\end{array}$ & $\begin{array}{l}22.4 \\
(1.4)\end{array}$ \\
\hline$V^{\prime} \mathrm{E} \quad \mathrm{L} \cdot \mathrm{min}^{-1}$ & $\begin{array}{c}6.4 \\
(0.9)\end{array}$ & $\begin{array}{c}5.7 \\
(0.8)\end{array}$ & $\begin{array}{l}5.5 \\
(0.5)\end{array}$ \\
\hline$V \mathrm{~T} \mathrm{~mL}$ & $\begin{array}{l}382.0 \\
(43.2)\end{array}$ & $\begin{array}{l}361.2 \\
(48.8)\end{array}$ & $\begin{array}{l}379.0 \\
(86.4)\end{array}$ \\
\hline$f \mathrm{R}$ breaths $\cdot \min ^{-1}$ & $\begin{array}{l}17.0 \\
(3.1)\end{array}$ & $\begin{array}{l}15.6 \\
(2.8)\end{array}$ & $\begin{array}{l}14.9 \\
(4.5)\end{array}$ \\
\hline$V \mathrm{~T} / t \mathrm{I} \quad \mathrm{L} \cdot \mathrm{s}^{-1}$ & $\begin{array}{l}311.0 \\
(45.0)\end{array}$ & $\begin{array}{l}314.0 \\
(81.4)\end{array}$ & $\begin{array}{l}308.6 \\
(22.2)\end{array}$ \\
\hline$t \mathrm{I} \mathrm{s}$ & $\begin{array}{c}1.31 \\
(0.34)\end{array}$ & $\begin{array}{c}1.37 \\
(0.37)\end{array}$ & $\begin{array}{c}1.44 \\
(0.56)\end{array}$ \\
\hline$t \mathrm{E} \mathrm{s}$ & $\begin{array}{c}2.15 \\
(0.42)\end{array}$ & $\begin{array}{c}2.40 \\
(0.44)\end{array}$ & $\begin{array}{l}2.70 \\
(0.79)^{*}\end{array}$ \\
\hline
\end{tabular}

$\overline{\text { All values are expressed as mean (SD). For definitions see leg- }}$ end to table $1 . *$ : $\mathrm{p}<0.05$ versus time 0 min.

statistical differences were not observed $(\mathrm{p}=0.09$ on D1 at the second hour). Mean $V \mathrm{~T} / \mathrm{t}$ f fell by $61.4(53.1) \mathrm{L} \cdot \mathrm{s}^{-1}$ on the day of haemodialysis without oxygen supplement $(\mathrm{p}=$ 0.054; table 1). On D2 it did not decrease with the progress of haemodialysis.

The mean $t \mathrm{E}$ was markedly increased on $\mathrm{D} 1$, from 1.98 $(0.46)$ to $2.57(0.53) \mathrm{s}(\mathrm{p}<0.001)$. This was due to both a decrease in $f \mathrm{R}(\mathrm{p}<0.001$; table 1$)$ and the occurrence of apnoeas. There was also an increase in $t \mathrm{E}$ on the day with oxygen administration. Mean $t \mathrm{E}$ was $2.15(0.42) \mathrm{s}$ before dialysis, rising to $2.7(0.79) \mathrm{s}$ by the second hour $(\mathrm{p}<0.05)$. Mean $t \mathrm{I}$ increased from $1.21(0.25)$ to $1.44(0.28) \mathrm{s}$ by 120 $\min (\mathrm{p}<0.05)$ on D1.

All predialysis ventilation parameters were similar on the two study days. It was noted, however, that the baseline $V^{\prime} \mathrm{E}$ on D2 was lower than that on D1 (tables 1, 2 and fig. 1). One possible explanation was that the amount of fluid overload was less on D2. Besides $\mathrm{Pa}_{\mathrm{a}} \mathrm{O}_{2}$, there was no statistical difference in predialysis blood gas measurements between the two days. The percentage differences from baseline of all ventilation parameters and blood gases were compared between the two days and no significant difference was found, except for $\mathrm{Pa}_{\mathrm{a}} \mathrm{O}_{2}$ (table 3 ).

The breathing patterns were analysed manually from the Gould recordings. Breathing was found to be irregular a)

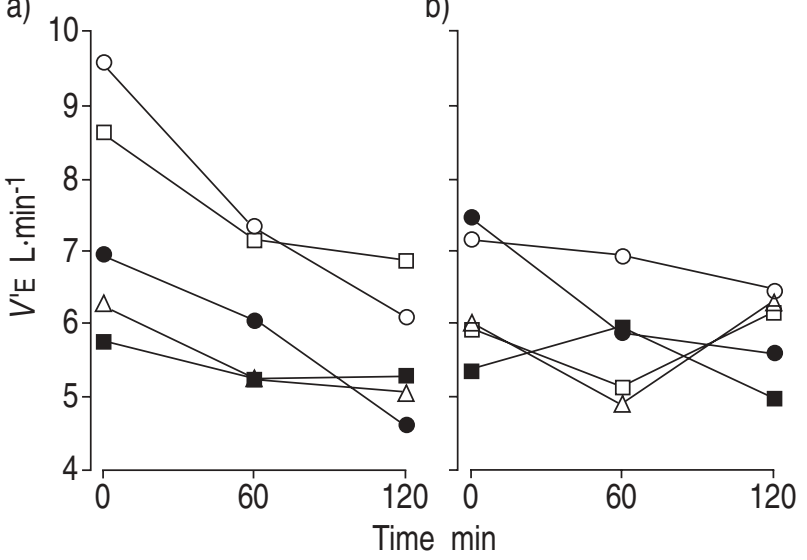

Fig. 1. - Individual minute ventilation ( $\left.V^{\prime} \mathrm{E}\right)$ data on a) D1 (second day dialysis) and b) D2 (third day dialysis intranasal oxygen).

with episodes of apnoea during the $2 \mathrm{~h}$ study on D1. On D2, periodic breathing and apnoeas were still present. All apnoeas were of the central type and analysed only when they were $>10 \mathrm{~s}$ in duration. Four out of the seven patients had more apnoeas on D2 (fig. 2). There was no significant difference in the number of apnoeas between the two days (table 4), although the mean number was higher on the day with oxygen administration. However, one of the patients had a large increase in the number of apnoeas ( 7 on D1 to 42 on D2) on the day with oxygen administration and this may have biased the mean result. The range of

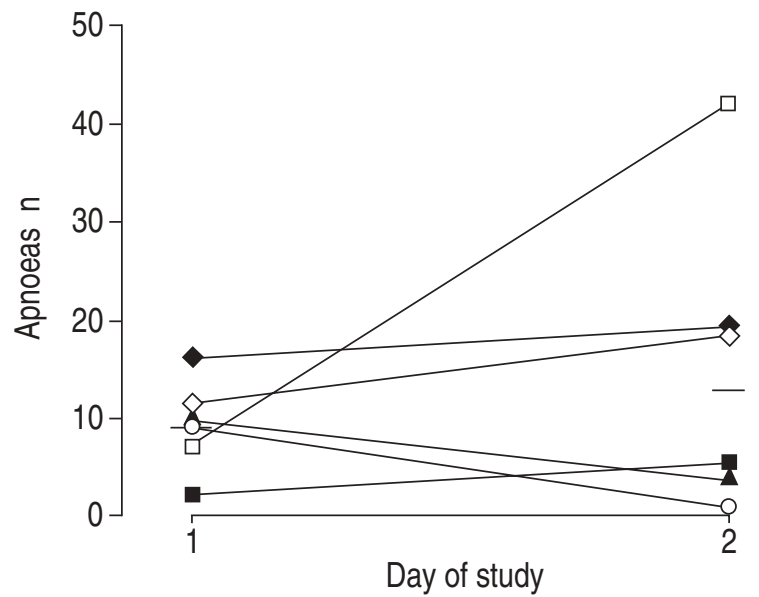

Fig. 2. - Number of central apnoeas for each individual on the two study days (D1 and D2). Horizontal line at each day indicates mean.

Table 3. - Comparison of per cent difference from baseline between the second and third days (D1 and D2)

\begin{tabular}{|c|c|c|c|c|c|c|c|c|c|}
\hline \multirow[b]{3}{*}{$P_{\mathrm{a}, \mathrm{O}_{2}}$} & \multirow[b]{3}{*}{$\%$} & \multicolumn{4}{|c|}{60 min from baseline } & \multicolumn{4}{|c|}{$120 \mathrm{~min}$ from baseline } \\
\hline & & \multicolumn{2}{|c|}{ D1 } & \multicolumn{2}{|c|}{ D2 } & \multicolumn{2}{|c|}{ D1 } & \multicolumn{2}{|c|}{$\mathrm{D} 2$} \\
\hline & & 14.6 & (7.6) & -11.1 & $(12.8) * * *$ & 13.7 & (6.2) & 5.1 & $(12.6) * *$ \\
\hline$P_{\mathrm{a}, \mathrm{CO}_{2}}$ & $\%$ & -1.6 & $(5.6)$ & 2.3 & $(7.2)$ & 3.1 & (6.8) & 6.5 & $(8.6)$ \\
\hline $\mathrm{pH}$ & $\%$ & -0.1 & $(0.2)$ & -0.06 & $(0.5)$ & -0.4 & $(0.3)$ & -0.5 & $(0.5)$ \\
\hline $\mathrm{HCO}_{3}$ & $\%$ & -3.2 & (6.8) & 1.3 & $(4.6)$ & -7.3 & (11.6) & -1.4 & (7.4) \\
\hline$V^{\prime} \mathrm{E}$ & $\%$ & 16.1 & $(5.4)$ & 9.4 & (13.2) & 24.0 & (11.3) & 11.9 & (14.1) \\
\hline$V \mathrm{~T}$ & $\%$ & 4.5 & (7.9) & 4.9 & (13.2) & 7.7 & (8.3) & 1.8 & (13.0) \\
\hline$f \mathrm{R}$ & $\%$ & 13.3 & $(9.3)$ & 7.7 & $(8.4)$ & 20.1 & $(7.8)$ & 13.2 & (15.4) \\
\hline$V \mathrm{~T} / t \mathrm{I}$ & $\%$ & 7.6 & (13.6) & -0.7 & (19.9) & 16.1 & (12.0) & -0.8 & (15.3) \\
\hline$t \mathrm{I}$ & $\%$ & -15.1 & (18.7) & -4.7 & $(8.8)$ & -19.7 & (16.7) & -10.1 & (33.4) \\
\hline$t \mathrm{E}$ & $\%$ & -22.0 & (17.2) & -12.4 & (12.1) & -30.9 & (12.0) & -24.3 & $(22.2)$ \\
\hline
\end{tabular}

All values are expressed as mean \pm sD. For definitions see legend to table $1 .{ }^{* *}: \mathrm{p}<0.01 ; * * *: \mathrm{p}<0.001$ between D1 and D2. 
Table 4. - Number and duration of apnoeas during the 2 h study

\begin{tabular}{|c|c|c|}
\hline & D1 & D2 \\
\hline \multicolumn{3}{|l|}{ Number } \\
\hline Mean (SD) & $9.1 \quad(4.2)$ & $13.4 \quad(14.5)$ \\
\hline Median & 9 & 5 \\
\hline Range & $(2-16)$ & $(1-42)$ \\
\hline \multicolumn{3}{|l|}{ Duration(s) } \\
\hline Mean (SD) & $15.8 \quad(4.3)$ & 15.8 \\
\hline
\end{tabular}

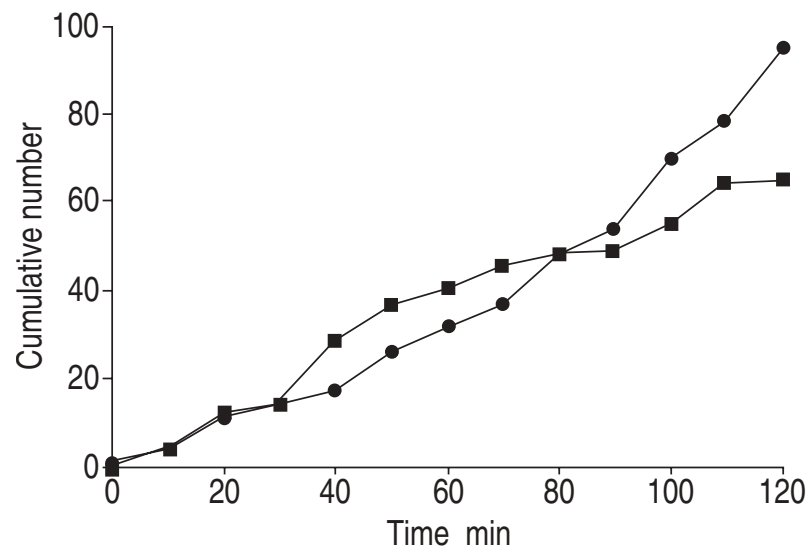

Fig. 3. - Cumulative number of central apnoeas $>10 \mathrm{~s}$ with time on D1 (•) and D2 (•) study days.

number of apnoeas was wide on D2. Therefore, the cumulative number of apnoeas (64 on D1 versus 94 on D2 over the $2 \mathrm{~h}$ study) was also studied and, as shown in figure 3 , the curves were similar and no statistical difference was obtained when the areas under the two curves were compared. The onset of apnoea on each study day was also examined. On D1, the mean onset was 16 (17) min, while that on D2 was 42.7 (44.4) min after the start of haemodialysis. The difference was not significant. The mean duration of apnoea was similar on both days, with the longest duration being $15 \mathrm{~s}$ on D1 and $29 \mathrm{~s}$ on D2. Breathing was irregular on both days and this was further confirmed by no difference in the coefficient of variation of $f \mathrm{R}$ (29.6 (11.9)\% on D1 versus 35.8 (5.1)\% on D2) or VT $(38.2$ (11.9)\% on D1 versus 40.5 (11.3)\% on D2) on both days at the second hour of the study.

\section{Discussion}

In this study, ventilation parameters and blood gases were measured in patients during haemodialysis for $2 \mathrm{~h}$. The validation of quantitative calibration was checked before the start and at the end of the study. The data from only five patients who had a mean validation per cent error of $\pm 10 \%$, and $90 \%$ of their breath-to-breath per cent error was $\pm 15 \%$, were used in the quantitative analysis of para-meters $\left(V^{\prime} \mathrm{E}, V_{\mathrm{T}}\right.$ and $\left.V \mathrm{~T} / t \mathrm{t}\right)$. The data from all patients were included in the analysis of the other measurements. RIP was used to overcome the problem of using a mouthpiece, which has been reported to influence the pattern of breathing via oral respiration. Oral breathing has been found to increase $V \mathrm{~T}$ and reduce $f \mathrm{R}[22]$.
The decrease in $\mathrm{Pa}_{\mathrm{a}} \mathrm{O}_{2}$ of $1.9 \mathrm{kPa}$, or $13.7 \%$ from baseline, in this study was consistent with previous studies [3, 12 ] and was associated with a decrease in $V^{\prime} E$. An irregular breathing pattern with episodes of central apnoea was demonstrated. The patients were observed to be awake during the study and this was further confirmed by the presence of activity on their wrist actigraphs. None of them was taking any medicine that could have led to respiratory suppression.

Administration of oxygen prevented the fall in $\mathrm{Pa}, \mathrm{O}_{2}$ but did not remove the irregular breathing. $V^{\prime} E$ continued to fall, although this was not significant. Percentage differences of change from baseline values were compared between the two days and no significant difference was shown. The breathing pattern remained irregular. The coefficient of variation of $f \mathrm{R}$ and $V \mathrm{~T}$ did not decrease with oxygen administration. The cumulative number of apnoeas over the $2 \mathrm{~h}$ was higher (94 versus 64) on D2 than on D1. Some patients experienced more prolonged central apnoeas. Oxygen administration had been shown to lengthen the duration of apnoea because of a decreased hypoxic sensitivity of the peripheral chemoreceptors as well as an increased cycle time of oscillation $[18,20]$. On D2, with $\mathrm{Pa}, \mathrm{O}_{2}$ maintained above $20 \mathrm{kPa}$, the hypoxic drive was removed. Extrapulmonary excretion of carbon dioxide continued during haemodialysis. The breathing pattern remained unstable. There was also a fall in $V^{\prime} \mathrm{E}$, although this was not significant.

Excess carbon dioxide and hydrogen ions affect respiration mainly by excitatory effects on the respiratory centre itself, whereas oxygen acts almost entirely on the peripheral chemoreceptors. These peripheral chemoreceptors also respond to carbon dioxide and hydrogen ions. The mechanisms of both carbon dioxide and hydrogen ion action are more important in the control of respiration. The effect of $\mathrm{Pa}_{\mathrm{a}} \mathrm{O}_{2}$ changes on respiratory control is opposed by both the carbon dioxide and the hydrogen ion control mechanisms. This is because the increase in ventilation that occurs when the $\mathrm{Pa}, \mathrm{O}_{2}$ falls, reduces the $\mathrm{Pa}_{\mathrm{a}} \mathrm{CO}_{2}$ and, at the same time, decreases the hydrogen ion concentration. The latter two therefore exert inhibitory effects that oppose the excitatory effect of the diminished $\mathrm{Pa}, \mathrm{O}_{2}$ [24]. The peripheral chemoreceptors become very sensitive to changes in $\mathrm{Pa}, \mathrm{O}_{2}$ only when it is below $8 \mathrm{kPa}$.

In this study, it was unlikely that hypoxaemia played a major role in producing the irregular breathing pattern with central apnoeas, as the $\mathrm{Pa}, \mathrm{O}_{2}$ did not fall below 10.7 $\mathrm{kPa}$ throughout the $2 \mathrm{~h}$ of study in all subjects. The carbon dioxide response could have played a more important role in causing the irregular breathing.

The lower end of the carbon dioxide response curve is flattened into a "dogleg" region in which carbon dioxide responsiveness is greatly reduced or absent [25-27]. At the junction of the "dogleg" and the steep point of the carbon dioxide response curve, breathing is not stable and central apnoeas occur. It could be explained that during haemodialysis with extrapulmonary carbon dioxide unloading, the patients were breathing at this junction. However, the "dogleg" region in the $V^{\prime} \mathrm{E}-\mathrm{P} \mathrm{a}, \mathrm{CO}_{2}$ curve occurs only in the presence of hypoxaemia with a $P \mathrm{a}, \mathrm{O}_{2}$ ð6.7 kPa $[24,25,28]$. Thus, this could not have explained the irregular breathing found in these patients.

In humans, apnoeas or unstable breathing patterns can be induced by small reductions in $\mathrm{Pa}_{\mathrm{a}} \mathrm{CO}_{2}$ below the resting 
level both in sleep $[29,30]$ and sometimes in the awake state [26, 31-33]. Venous carbon dioxide unloading by haemodialysis $[16,27]$ and the ventilatory response to transient carbon dioxide pulses during recovery from voluntary overbreathing [34] suggested that the apnoeic threshold for $\mathrm{Pa}_{\mathrm{a}} \mathrm{CO}_{2}$ may be up to $1.3 \mathrm{kPa}$ below the resting level, but with wide individual variation. The threshold level of $P \mathrm{a}, \mathrm{CO}_{2}$ needed to eliminate spontaneous breathing depends on $\mathrm{Pa}, \mathrm{O}_{2}$ and breathing terminates at a lower level of $\mathrm{Pa}, \mathrm{CO}_{2}$ with hypoxaemia than with hyperoxia. The threshold level of chemical stimulation needed to initiate peripheral chemoreceptor activity may be less than that required to trigger central chemoreceptor discharge [20, $35,36]$. Increasing hypocapnia, nonetheless, eventually silences the peripheral chemoreceptors. A comparative study between the peripheral chemoreceptor stimulating agent almitrine and the mainly central stimulating acetazolamide showed that central chemoreceptor stimulation eliminated periodic breathing, whereas peripheral stimulation enhanced breathing instability [37]. It may be postulated that with carbon dioxide unloading during acetate containing dialysate haemodialysis, the central chemoreceptors were inactivated, leaving the peripheral chemoreceptors responding to the changes in $\mathrm{Pa}_{2} \mathrm{CO}_{2}$ and $\mathrm{Pa}, \mathrm{O}_{2}$, resulting in irregular breathing and central apnoeas. When $P \mathrm{a}, \mathrm{O}_{2}$ was raised with oxygen administration, this carbon dioxide apnoeic threshold may have been increased [25, 38]. The correction of acidosis also raised the threshold level [38]. The fall in $\mathrm{Pa}, \mathrm{CO}_{2}$ on D2 was greater. One possible reason for the higher carbon dioxide unloading on D2 may be due to the blood flow. However, in this study, the dialysate flow and blood flow rates were kept constant on the two days. With a higher threshold value, more central apnoeas were encountered and an irregular breathing pattern continued despite an improvement in $\mathrm{Pa}, \mathrm{O}_{2}$. BERSSENBRUGG et al. [19] found that hypoxaemia-induced periodic breathing required the presence of hypocapnia and that hypocapnia, even in the absence of hypoxaemia, continued to elicit irregular breathing. Furthermore, irregular breathing could be improved by the inhalation of carbon dioxide $[18,20]$ and it is postulated that the peripheral chemoreceptor response to $\mathrm{Pa}, \mathrm{CO}_{2}$ may be more important in causing these breathing patterns. Another study with car-bon dioxide and oxygen administration should be underta-ken to determine whether regular breathing can be restored.

The finding that oxygen administration did not eliminate the irregular breathing pattern was in contrast to that in a similar study by Heyrman et al. [21]. However, the design of their study was different from that of the present study. Their subjects were given 30 min of oxygen administration after $130 \mathrm{~min}$ of dialysis, while the present subjects had $120 \mathrm{~min}$ from the start of haemodialysis. The mean onset of central apnoeas was 42.7 (44.4) min after the start of haemodialysis on the third study day compared with 16 (17) min on the second study day. The present subjects were given a longer duration of oxygen, which could have accounted for the differences in the results.

Acknowledgements: The authors would like to thank A. Phe, statistician of the Research and Evaluation Dept for her help in the statistical analysis of the data, and C.H. Lim, Head of the Renal Dept of SGH PTE, Ltd, for his permission to study the seven patients in the Dialysis Centre at Tan Tock
Seng Hospital.

\section{References}

1. Cardoso M, Vinay P, Vinet B, et al. Hypoxaemia during haemodialysis: a critical review of the facts. Am J Kidney Dis 1988; 11: 281-297.

2. de Broe ME, Heyrman RM, de Backer WA, Verpooten GA, Vermeire PA. Pathogenesis of dialysis-induced hypoxemia: a short review. Kidney Int 1988; 33: 4 Suppl. 24, $57-61$.

3. Eiser AR. Pulmonary gas exchange during haemodialysis and peritoneal dialysis: interaction between respiration and metabolism. Am J Kidney Dis 1985; 6: 131-142.

4. Martin L. Hypoventilation without elevated carbon dioxide tension. Chest 1980; 77: 720-721.

5. Sherlock J, Ledwith J, Letteri J. Determinants of oxygenation during haemodialysis and related procedures: a report of data acquired under varying conditions and a review of the literature. Am J Nephrol 1984; 4: 158-168.

6. de Backer WA, Verpooten GA, Borgonjon DJ, Vermeire PA, Lins RR, de Broe ME. Hypoxemia during haemodialysis: effects of different membranes and dialysate compositions. Kidney Int 1983; 23: 738-743.

7. Hakim RM, Lowrie EG. Haemodialysis-associated neutropenia and hypoxemia: the effect of dialyzer membrane materials. Nephron 1982; 32: 32-39.

8. Kaplow LS, Goffinet JA. Profound neutropenia during the early phase of haemodialysis. JAMA 1968; 203: 11351137.

9. Craddock PR, Fehr J, Brigham KL, Kronenberg RS, Jacob HS. Complement and leukocyte-mediated pulmonary dysfunction in haemodialysis. N Engl J Med 1977; 296: 769-774.

10. Sherlock J, Ledwith J, Letteri J. Hypoventilation and hypoxia during haemodiaysis: reflex response to removal of $\mathrm{CO}_{2}$ across the dialyzer. Trans Am Soc Artif Intern Organs 1977; XXIII: 406-410.

11. Aurigemma NM, Feldman NT, Gottlieb M, Ingram RH Jr, Lazarus JM, Lowrie EG. Arterial oxygenation during haemodialysis. N Engl J Med 1977; 297: 871-873.

12. Oh MS, Uribarri J, Del Monte ML, et al. A mechanism of hypoxemia during haemodialysis: consumption of $\mathrm{CO}_{2}$ in metabolism of acetate. Am J Nephrol 1985; 5: 366-371.

13. Serrano RP, Vega FF, Grande JA. Hypoxemia during haemodialysis in patients with impairment in pulmonary function. Nephron 1986; 42: 14-18.

14. Vinay P, Cardoso M, Tejedor A, et al. Acetate metabolism during haemodialysis: metabolic considerations. Am J Nephrol 1987; 7: 337-354.

15. Mahajan SK, Gardiner WH, Muller B, Desai S, Briggs WA, McDonald FD. Correction of haemodialysis induced hypoxemia by increasing fraction of inspired oxygen $\left(F_{\mathrm{I}}, \mathrm{O}_{2}\right)$. Trans Am Soc Artif Intern Organs 1978; XXIV: 462-464.

16. de Backer WA, Heyrman RM, Wittesaele WM, Waeleghem JPV, Vermeire PA, de Broe ME. Ventilation and breathing patterns during haemodialysis-induced carbon dioxide unloading. Am Rev Respir Dis 1987; 136: 406-410.

17. Chadha TS, Birchs S, Sackner MA. Periodic breathing triggered by hypoxia in normal awake adults: modification by naloxone. Chest 1985; 88: 16-23.

18. Khoo MCK, Kronauer RE, Strohl KP, Slutsky AS. Factors inducing periodic breathing in humans: a general model. J Appl Physiol: Respir Environ Exercise Physiol 
1982; 53: 644-659.

19. Berssenbrugg A, Dempsey J, Iber C, Skatrud J, Wilson P. Mechanisms of hypoxia-induced periodic breathing during sleep in humans. J Physiol (Lond) 1983; 343: 507-524.

20. Cherniack NS, Longobardo GS. Abnormalities in respiratory rhythm. In: Cherniack NS, Widdicombe JG, eds. Handbook of Physiology. Section 3. The Respiratory System. Volume II: Control of Breathing, Part 2. Bethesda, MD, American Physiological Society, 1986; pp. 729-749.

21. Heyrman RM, de Backer WA, Van Waeleghem JP, Willemen MJ, Vermeire PA, de Broe ME. Effect of oxygen administration on the breathing pattern during haemodialysis in man. Eur Respir J 1989; 2: 972-976.

22. Rodenstein DO, Mercenier C, Stanescu DC. Influence of the respiratory route on the resting breathing patterns in humans. Am Rev Respir Dis 1985; 131: 163-166.

23. Sackner MA, Watson H, Belsito AS, et al. Calibration of respiratory inductive plethysmograph during natural breathing. J Appl Physiol 1989; 66: 410-420.

24. Guyton AC. Regulation of Respiration. In: Guyton AC, ed. Textbook of Medical Physiology. Philadelphia, PA, W.B. Saunders, 1986; pp. 504-515.

25. Cunningham DJC, Robbins PA, Wolff CB. Integration of respiratory responses to changes in alveolar partial pressures of $\mathrm{CO}_{2}$ and $\mathrm{O}_{2}$ and in arterial $\mathrm{pH}$. In: Cherniack NS, Widdicombe JG, eds. Handbook of Physiology. Section 3: The Respiratory System. Volume II: Control of Breathing, Part 2. Bethesda, MD, American Physiological Society, 1986; pp. 475-528.

26. Gardner WN. The $\mathrm{CO}_{2}$ response: usefulness and uncertainties. Eur Respir J 1993; 6: 611-613.

27. de Backer W. Clinical significance of studying resting $\mathrm{CO}_{2}$ drive after $\mathrm{CO}_{2}$ unloading. Eur Respir J 1992; 5: 507-508.

28. Nielsen M, Smith H. Studies on the regulation of respira- tion in acute hypoxia. Acta Physiol Scand 1951; 24: 293 313.

29. Skatrud JB, Dempsey JA. Interaction of sleep state and chemical stimuli in sustaining rhythmic ventilation. $J$ Appl Physiol: Respir Environ Exercise Physiol 1983; 55: 813822.

30. Datta AK, Shea SA, Horner RL, Guz A. The influence of induced hypocapnia and sleep on the endogenous respiratory rhythm in humans. J Physiol 1991; 440: 17-33.

31. Haldane JS, Poulton EP. The effects of want of oxygen on respiration. J Physiol 1908; 37: 390-407.

32. Bainton CR, Mitchell RA. Post-hyperventilation apnea in awake man. J Appl Physiol 1966; 21: 411-415.

33. Gardner WN, Meah MS. Incidence of apnoea following voluntary hyperventilation in man. $J$ Physiol 1989; 409: 67P.

34. Cummin ARC, Sidhu VS, Telford RJ, Saunders KB. Ventilatory responsiveness to carbon dioxide below the normal control point in conscious normoxic humans. Eur Respir J 1992; 5: 512-516.

35. Casey K, Duffin J, McAvoy GV. The effect of exercise on the central chemoreceptor threshold in man. $J$ Physiol 1987; 383: 9-18.

36. Duffin J, McAvoy GV. The peripheral chemoreceptor threshold to carbon dioxide in man. J Physiol 1988; 406: 15-26.

37. Hackett P, Reeves J, Reeves C, Grover R, Rennie D. Control of breathing in Sherpas at low and high altitude. $J$ Appl Physiol: Respir Environ Exercise Physiol 1980; 49: 374-379.

38. Anderton JL, Harris EA, Robson JS. The ventilatory response to carbon dioxide and hydrogen ion in renal failure. Clin Sci 1965; 28: 251-258. 